\title{
Oleandomycin Phosphate
}

National Cancer Institute

\section{Source}

National Cancer Institute. Oleandomycin Phosphate. NCI Thesaurus. Code C61865.

The phosphate salt form of oleandomycin, a macrolide antibiotic similar to erythromycin with antimicrobial activity. Oleandomycin targets and reversibly binds to the 50S subunit of bacterial ribosomes. This prevents translocation of peptidyl tRNA leading to an inhibition of protein synthesis. 